\title{
Review
}

\section{Value Chain Analysis: Overview and Context for Development}

\section{Fonseca, Cristino Mandinga Bonfim ${ }^{1 *}$, Coelho, José Castro ${ }^{2}$, Soares, Fernando Brito ${ }^{3}$ and Correia, Augusto Manuel Nogueira Gomes ${ }^{4}$}

\author{
${ }^{1}$ Tropical Knowledge and Management Program, Universidade Nova de Lisboa-NOVA School of Business and \\ Economics, Portugal. \\ ${ }^{2}$ Associate professor with aggregation at Instituto Superior de Agronomia from Universidade de Lisboa. \\ ${ }^{3}$ Professor of Economics at Nova School of Business and Economics. \\ ${ }^{4}$ Associate professor with aggregation at Instituto Superior de Agronomia from Universidade de Lisboa, and member of \\ Executive Board of CTA. \\ *Corresponding Author E-mail: cristinofonseca@hotmail.com
}

Received 30 November 2019; Accepted 14 December, 2019

The term "value chain" as well as the method of value chain analysis have their origins in two concepts: the francophone term of "filiére"; and the anglophone term of "commodity chain". In the last two decades, value chain analyses have been widely used by public and international agencies in their programs and projects for development, mainly in the agricultural sector, as it involves many poor people. The use of value chain analysis will continue to grow because it is a very useful tool. However, the framework of such analyses depends on the objectives and the context (which determine the nature of the analysis - qualitative and/or quantitative), the focus (products, activities, or actors), the policyoption evaluations, and whether or not the goal is to assess environmental dimension(s) (impact measuring). In the present study, three value chain analyses were analyzed: FAO - value chain analysis; Value links manual and the recent Value Chain Analysis for Development. The last of these was found to be the most updated, because it includes in its own structure a qualitative and quantitative analysis, providing a robust and detailed environmental and social dimension evaluation, and reflects a concern about the sustainability of the value chain.

Keywords: Value chain, sustainability, income, poverty, environment

\section{INTRODUCTION}

The concept of value chain (VC) refers to the full range of activities that are required to bring a product (or a service) from conception, through the different phases of production, to its delivery to final consumers, and disposal after use (Kaplinsky, 2000; Kaplinsky and Morris, 2001; DFID, 2008). Initially, the VC literature fell into the realm of management studies, but in the last two decades a new perspective has arisen, linked with Development Economics. Not only researchers such as sociologists, but also economists, International Organizations (e.g. Food and Agriculture Organizations (FAO), and Non-Governmental Organizations (NGO) have used value-chain theory and methodologies (e.g. global commodity chains) in their research, analyses (at the level of firms, industries, and countries), projects, and intervention policies (Gereffi, 1999; Gibbon et al.,2008; Gereffi and Fernandez-Stark, 2016).

In this sense, Value Chains Analysis (VCA) has been applied for the most part in developing countries (DC) (Trienekens, 2011) and is the driver of the new strategy of public and international agencies to conduct their projects and development programs addressing the private sector (Pietrobelli and Staritz, 2013; Simatupang et al.,2017). Many methodologies and approaches have 
been drawn upon for qualitative or quantitative analysis or both, but not all use an accounting framework addressing the environmental dimension or have at the core of its methodology the social and environmental issues. However, it is necessary for environmental analysis that, beyond evaluating the impact of VC activities and methods, also includes valuing farmers' available environmental assets.

The research reported here starts with a contextualization of the VC concept and the framework of VCA. In the second part three VCA methodologies (FAOVCA, ValueLinks, and Value Chains Analysis Four Development) are discussed. As the value chains analysis for development (VCA4D) is more recent and framed according to social and environmental parameters, more details are provided. All of these methodologies can be addressed to agricultural products. But normally VCA differs according to scope, product, or activity (Fabe et al., 2011; FAO, 2013). Thus, in analyzing these methodologies the focus was on the type of analysis (qualitative/quantitative), and the structure/framework.

\section{DISCUSSIONS}

\section{Context of value chain}

VC study, its theory, analysis, and methodologies, are rooted in two concepts, the francophone concept of filière, and the anglophone concept of commodity chain (Raikeset al., 2000). The filière concept is a technical framework for practical research wedded to the commodity chain concept, which is more theoretical and focuses on industrial commodities chains.

The filière arose during the 1960s, developed by the French National Institute for Agricultural Research and the French Agricultural Research Centre for International Development. It was first applied in studies about contract farming and vertical integration in French agriculture, and second to the linkage between the French state and France's former colonies through traditional commodities such as cocoa, coffee, rubber, and also to the agricultural development policies for these ex-colonies (Raikes et al.,2000; Fabe et al.,2009; Drost et al.,2010; Bellù, 2013). According to Webber and Labaste, (2009), the "French Filière Approach" (FFA) can be used as a synonym for commodity chain. However, it is less theoretical than the commodity chain concept as well as being essentially practical and quantitative (Raikes et al., 2000; Kaplinsky and Morris, 2001; Altenburg, 2006; Drost et al., 2010). The quantitative dimension of FFA is useful for VCA because development practitioners need to account for indicators like price, profit, inputs, outputs, and value-added along the chain, and how they are distributed. The FFA framework allows us to map the physical (agents, activities, inputs, and outputs), and the money flows, which is in agreement with new methodologies and VC analysis, although being at local and national level (Kaplinsky and Morris 2001; Fabe et al., 2009).

In relation to the commodity chain, the study first highlights the "supply chain" management term, introduced by consultants Oliver and Webber in 1982 (Svensson, 2007; Farahani et al.,2009; Sweeney, 2010).

Later, Hopkins and Wallerstein (1986), as cited by Gereffi and Korzeniewicz (1994), introduced the commodity chain concept that arises from the dependence theory of the 1970s and 1980s (Fabe et al., 2009; Drost et al., 2010). It is usually used to refer to the pattern in the world economy of all necessary activities including conception, transformation, design, and disposal after use of each product (Gereffi, 1999; Dougherty, 2008).

In the 1980s, based on the "supply chain" concept, Michel Porter developed the term 'VC applicable to firms' analysis", referring to this as a set of activities (logistic, marketing, production, delivery, and design) that is strategic for firms due to the value-added generated (Porter, 1985; Fabe et al., 2009; Drost et al., 2010; Zamora, 2016; Simatupang et al., 2017).

The globalization process is more than more-integrated international trade. It also means the tie of networks, partnerships, and the internationalization of production systems (Gereffi, 1994; Gereffi et al., 2005). In this sense, to study the geographic distribution of chains that are dispersed, and their fragmented organizational structure, Gereffi, (1994 and 1999) developed the theory of Global Commodity Chain (GCC). The author highlights the increasing importance of some key actors of these chains, such as retailers and brand marketers (Gereffi and Korzeniewicz, 1994; Raikes et al., 2000; Altenburg, 2006). The main contribution of GCC was the definition of two types of governance of VC, Producer-driven (PD), and Buyer-driven (BD) (Gibbon and Ponte, 2005; Bair, 2005; Sturgeon, 2009). PD cover chains characterized by capital and technology-intensity and these chains are controlled by transnational corporations (e.g. automobiles, aircraft, computers), and the BD chains by labor-intensity, and the key drivers are buyers such as retailers and brand marketers (Gereffi, 1994; Gereffi, 1999).

However, the GCC is very restricted because agricultural products without commodities characteristics were not included in this approach (Gibbon and Ponte, 2005), nor was the service sector (Gereffi, 1994; Raikes et al., 2000; Bair, 2009). That is why Gereffi introduced another theory, the Global Value Chain (GVC), which focuses its analysis on the network as the driver for the evolution of industrial organization at cross-border.

There are five types of governance in the GVC literature (market, modular, relational, captive, and hierarchy), which is more elaborate than $\mathrm{PD}$ and $\mathrm{BD}$ from the GCC theory. The complexity of information, codifying 
of information for production, and the level of supplier competence are the determinant variables that are used to measure these five types of governance (Bair, 2005; Sturgeon, 2008; Gereffi and Fernandez-Stark, 2016). Based on these five types of governance, it is possible to explain the new analyses of VC as carried out by Dolan and Humphrey, (2000) about fresh vegetables from African countries to UK supermarkets (Gereffi et al., 2005).

Another recent approach of the VC literature is the "World Economic Triangle" (Fabe et al., 2009), which means interaction with two new governance structures (global value chains and global standards), and regions in the world economy (Messner, 2002; Schmitz, 2004). Actually, the international market develops at the transnational level, so the first step is to improve the competitivity of regions, and in this sense the support of multilateral organizations such as the World Trade Organization and NGOs is important mainly for developing countries and their businesses and farmers; and the second step, to establish transnational relations and good network structures.

Understanding the world economic framework and its governance is important because it allows us to identify where and what are the opportunities and risks in the VC. It is also necessary to develop mechanisms to protect unfavorable smallholder farmers, empower them, and create conditions to reduce the transaction costs through technical and financial support for their full participation in more globalized and competitive markets. The farmers' position must be improved in the chain (Pietrobelli and Staritz, 2013), and solve constraints such as lack of credit and institutional technical support that become these competitive chains unfavorable for them.

Thus, the VCA can be seen as an innovation in development studies literature, because they enable, for example, the development practitioners to draw the profile of economic activities in society at different phases from production to consumption, and their backward and forward linkage among their different players (Gereffi, 1994; Visser et al., 2012). The VCA can still be used as a management tool, in this case useful for local planning (EC, 2011).

Taking into account the nature of these analyses, their use to elaborate intervention programs and development projects reoccurs again and again (Fabe et al., 2011; Pietrobelli and Staritz, 2013; Donovan et al., 2015) and is widely applied because, contrasting with most theoretical concepts of VC described above, many VCA include both quantitative and qualitative analysis features and a corresponding accounting tool (e.g. FAO-VCA, described below). These useful analyses now included in the last year other approaches that have an accounting framework for environmental economics (Fabe et al., 2011).

In this sense, VCA has been largely applied to the agricultural value chain, e.g., cashew nuts in Mozambique
(Antonio and Griffith, 2017) and African horticulture (Dolan and Humphrey, 2000). The focus will remain on the agricultural sector mainly for two reasons. First, it is the most efficient sector for poverty mitigation (Webber and Labaste, 2010; EC, 2011; Deutsch Bank, 2014), and and second, is often the dominant sector in DC (Trienekens, 2011). It is therefore expectable that VCA will continue to rise in coming years, as in the cases of "Model for Sustainability Smallholder Inclusion in HighValue-Agro-food Chains" and "Value Chains Analysis for Development" (Gibbon et al., 2008; Gereffi and Fernandez-Stark, 2016; EC, 2017a).

\section{Value chains analysis and the relationship with the agricultural sector and poverty}

Economic growth is the way to achieve economic progress, but for a full and sustainable well-being, social and environmental improvements are also needed. VCA addresses the agricultural producers' need to improve their sustainable performance, adopting social, and environmental quantitative procedures (Ambec et al., 2013; Messner, 2002) made possible by VCA4D. According to the current agenda of Sustainable Development Goals (SDG) (Fabe et al., 2011) sustainability cannot be an entirely economic analysis. In some cases, it is even insufficient and/or inappropriate to evaluate poverty mitigation (Raikes et al., 2000; Rich et al., 2011). A broad VCA that covers social and environmental parameters allows for the VC under scrutiny to achieve a better competitive advantage with earnings for all VC players (Zamora, 2016). Therefore, VCA has been extended to cover environmental economics, calculating both the cost and benefits from VC activities and production methods evaluation (Fabe et al., 2011). Tools such as Life Cycle Assessment (LCA) and material flow analysis were developed to calculate the impact of VC activities regarding natural resources (Fabe et al., 2009 and 2011). These complementary tools that depend on the VCA framework can be adjusted to it (e.g. VCA4D the use LCA) for a more complete and inclusive analysis.

\section{VCA methodologies analyzed}

\section{FAO-VCA}

FAO-VCA is a practical methodology for policymaking that on the one hand affords us a quick VC analysis, and on the other hand makes a quantitative analysis of the impact of the policy options based on VC scenarios (Bellù, 2013). The main VC analysis points are socioeconomic context, demand for VC outputs, analysis of the institutional set-up, analysis of inputs and output 
markets, functional analysis of the VC (for functional analysis see Bockel and Tallec, 2005a, and the economic analysis of VC (for economic analysis see Bockel and Tallec, 2005b). Concerning the quantitative analysis of this methodology in relation to the policy implications of VC, the main points are (i) counterfactual analysis for policy impacts, (ii) calculation of parity price, (iii) the market price and real social value of goods and services using reference price, (iv) calculation of reference price, and finally, (v) calculation and comparison of net benefits for private agents and society. The accounting framework of FAO-VCA is quite wide, covering areas such as economic activity and farm management, industrial economics, national accounts, cost and benefit analysis for investment, welfare economics, international trade, and contract and game theory (Bellù, 2013), justifying the attention given to the political, social, and legal environment when it was conceived (Donovan et al., 2015). For FAO-VCA usage, the FAO VCA-Tool software was developed, i.e., the accounting framework. This software, which has been applied in several countries, allows us to calculate indicators such as profit from different activities and agents, value-added creation, and distribution in the VC (Bellù, 2013). The guidelines for its installation and handling were provided in Bellù (2012), for version 3.1.

\section{The ValueLinks manual}

"ValueLinks Manual is one of the most important manuals of ValueLinks methodology" (GTZ, 2007). This book provides a qualitative analysis with guidelines for promoting economic development based in a value chain perspective. Module 2 of this manual refers to the economic analysis of $\mathrm{VC}$, provides guidelines for valueadded and cost of production calculation. As this manual was built with empirical studies from development programs and promotion actions in private-sector with the support of the German Technical Cooperation, it is also very often associated with the public agencies and development projects. The core of this approach is the governance and upgrading which is fundamental for VC development, and in addition, monitoring is also well treated in the book (Donovan et al., 2015). ValueLinks presents the following structure: 12 modules $(0-11)$, with Know-how and guidelines for promoting each VC and farmers and small and micro-enterprises involved in the VC business. The 12 modules are: (0) Deciding whether to engage in value chain promotion, (1) select the value chain for promotion, (2) analyzing the value chain, (3) determining the chain upgrading strategy, (4) facilitating the chain development process, (5) strengthening private business linkages, (6) engaging in public-private partnerships, (7) strengthening services in VC, (8) financing VC, (9) introducing social, ecological, and product quality standards, (10) improving the business environment of $\mathrm{VC}$, and (11) monitoring and mapping impact (GTZ, 2007). The ValueLinks manual is quite broad, as it includes other approaches in its conceptual framework, for instance, modules 5-10, which focus on development projects. In relation to the VCA itself, the related modules are 1-4 and 11 .

\section{Value chain analysis for development}

\section{VCA4D framework}

This methodology has resulted from a multidisciplinary team built between DEVCO ${ }^{1}$ and AGRINATURA ${ }^{2}$ (EC, 2017b). The European Union (EU) is committed to sustainable development and has been upgrading its actions. Today it is the largest donor of official development aid, covering $60 \%$ of the total (Parlamento Europeu, 2015; OECD, 2016; Council of the Europe Union, 2017). In the context of external policy, the EU has chosen sustainable agriculture, because of its ability to generate value and create jobs in different sectors of society (EC, 2011; 2017a).

The success of VCA4D requires transparency and accountability in order to achieve robust economic growth, and its benefits reach the target group such as unfavoured smallholder farmers (EC, 2011 and 2017a).

\section{The VCA4D structure}

The VCA4D structure is divided into two parts: (i) the functional analysis and (ii) the sustainability analysis for social, economic, socioeconomic, and environmental dimensions.

\section{Functional analysis}

The three phases of functional analysis are; (i) overall description and mapping the VC system; (ii) main

${ }^{1}$ DEVCO - DEVCO or Directorate-General for International Cooperation and Development (DG DEVCO) is an EC institution responsible for definition of international cooperation policies and development of EU and provides aid worldwide. (Source: EC - International Cooperation and

Development:https://ec.europa.eu/europeaid/acerca-da-dgcooperacao-internacional-e-desenvolvimento-dg-devco_pt (27/02/2018).

${ }^{2}$ AGRINATURA - is a partne).rship with universities and research centers of 27 member states of the EU. The objective of this partnership is to promote agrarian development and improve living conditions throughout the world. Source: AGRINATURA: http://agrinaturaeu.eu/about-us/ (27/02/2018). 
Table1. The four farming questions of VCA4D.

\begin{tabular}{|c|c|}
\hline Farming questions & Man point \\
\hline What is the contribution of the VC to sustainable economic growth? & General domestic growth; and total value-added. \\
\hline Is this economic growth inclusive? & $\begin{array}{l}\text { Income generated and distributed among VC } \\
\text { actors. }\end{array}$ \\
\hline Is the VC socially sustainable? & $\begin{array}{l}\text { Working conditions; land and water rights; gender } \\
\text { equality; food and nutrition security; social capital; } \\
\text { and living conditions. }\end{array}$ \\
\hline Is the VC environmentally sustainable? & Impact measure using life-cycle assessment. \\
\hline
\end{tabular}

Source: Adapted from EC (2017a and 2017b).

features of technical diagnosis; and (iii) understanding the governance of VC (EC, 2017a). Regarding the overall description and mapping of the VC system, the objective is the design of the processes along the chain and the players involved. The main characteristic of the technical diagnosis is related to the identification of companies and their activity in the chain. Finally, "Understanding the governance", identifies the governance structure, which is important to understand the distribution of power and the profile of VC activities in the society.

\section{The perspective of sustainability of VCA4D methodology}

The second part of this methodology is divided into four framing questions, according to the following dimensions: social, economic, socioeconomic and environmental (Table 1).

\section{Conclusion}

There are many ambiguities in relation to the concepts and approaches of VC and future works should reflect this issue. Regarding the three VCAs discussed, we concluded that in addition to being more recent, the VCA4D is also more updated, because first, it encompasses the life-cycle assessment in its own structure to conduct a quantitative analysis of environmental impacts of VC activities, and second, its framework is according to the SDG, due to its strong sustainability component providing a social and socioeconomic analysis around the VC. Neither FAOVCA nor ValueLinks manual use LCA or other approaches to evaluate the environmental impacts. However, FAO-VCA suggests modeling of the environmental impact to evaluate the policy options and provides a good socio-economic analysis for VC. Regarding the ValueLinks manual, it is more qualitative than quantitative, and the main point to highlight is the know-how from development projects used to define this methodology, which is useful for development practitioners in DC. In short, sustainability has become the core of VCA, and this is the right way to evolve because progress is possible only in an inclusive environment. However, the VCA methodologies must also evolve in three directions. First, define clearly the role of state in the VC promoted; in this account, Dougherty, (2008) said that undervaluation of the role of the state is one of the analytical limitations of the commodity chain analysis. Second, seek to frame the information and communication technologies (ICT) in the VCA framework, because ICT has been accelerating the globalization of countries and firms and an inclusive VC also includes the technological dimension. What are the role and opportunities provided by ICT, and how to proceed to technology changes and the interaction with new technology and local know-how? These are important questions to solve. Thirdly, to define the model (e.g. public-private partnerships) of the $\mathrm{VC}$ and conditions to apply them. To frame the VC model the researchers can draw upon many of the related case studies and empirical evidence from programs and development projects of public and international organizations.

\section{Acknowledgment}

We thank the International Rice Research Institute (IRRI) for the scholarship provided, as well as the institutions supporting the PhD program "Tropical Knowledge and Management" at Nova School of Business and Economics.

\section{Authors' declaration}

We declared that this review was carried out by our research team and we agree to publish it in the journal.

\section{REFERENCES}

Altenburg T (2006). Donor Approaches to Supporting Pro-Poor Value Chains. German Development Institute. Report prepared for the Donor Committee for Enterprise Development Working Group on Linkages and Value Chains.

Ambec S, Cohen MA, Elgie S, Lanoie P (2013). The Porter Hypothesis at 20: Can Environmental Regulation Enhance Innovation and Competitiveness? Oxford University Press.

Antonio L, Griffith G (2017). The cashew in Mozambique: Analysis of performance and suggestions for improvement. International Journal 
on Food System Dynamics, 8 (1): 208-221. DOI:http://dx.doi.org/10.18461/ijfsd.v8i3.833

Bair J (ed.) (2009). Frontiers of Commodity Chain Research. Stanford, California. Stanford University Press.

Bellù LG (2012). FAO VCA-Toll: a software for value chain analysis. Manual for Version 3.1. EASYPol Series 074. FAO.

Bockel L, Tallec F (2005a). Commodity chain analysis. Constructing the commodity chain functional analysis and flow charts. EASYPol module 03. FAO.

Bockel L, Tallec F (2005b). Commodity chain analysis. Financial analysis. EASYPol module 044. FAO.

Council of the EU (2017). Novo Consenso Europeu sobre o Desenvolvimento, EU e Estados-Membros assinam estratégia conjunta para erradicar a pobreza. Press office - General Secretariat of the Council. Comunicado de Imprensa, 340/17 - 07/06/2017.

Deutsch Bank (2014). Agricultural value chains in Sub-Saharan Africa: From a development challenge to business opportunity. Current Issues - Emerging markets. Deutsche Bank, Research.

DFID (2008). Making Value Chains Work Better for the Poor: A Toolbook for Practitioners of Value Chain Analysis, Version 3. Edited by Tim Purcell, Stephen Gniel, and Rudy van Gent. Making Markets Work Better for the Poor (M4P) Project, UK Department for International Development (DFID). Agricultural Development International: Phnom Penh, Cambodia.

Dolan C, Humphrey $J$ (2000). Governance and trade in fresh vegetables: the impact of UK supermarkets on the African horticulture industry. The Journal of Development Studies, 37 (2):147-176. DOI: $10.1080 / 713600072$.

Donovan J, Franzel S, Cunha M, Gyau A, Mithofer D (2015). Guides for value chain development: a comparative review. Journal of Agribusiness in Developing and Emerging Economies, 5 (1):2-23. DOI: 10.1108/JADEE-07-2013-0025.

Dougherty $\mathrm{Ml}$ (2008). Theorizing Theory: Origins and orientations of commodity chain analysis. The Global Studies Journal, 1(3):29-38.

Drost S, Van Wijk J, Vallema S (2010). Development Value Chains Meet Business Supply Chains, The concept of global value chains unraveled. The Partnership Resource Centre: Working Paper - 002.

(EC) European Commission (2011). Rural Development, Food Security and Nutrition - Analysis and Development of Inclusive Value Chains To Support Small-Scale Producers to Access Agricultural Markets. EuropeAid. Information note.

(EC) European Commission (2017a). VCA4D, Methodological Brief. Frame and Tools, key features of the experts' work.

(EC) European Commission (2017b). Value Chain Analysis for Development (VCA4D). Providing Value Chain Analysis for improving operations. Why? What? How? Directorate General International Cooperation and Development - EuropeAid. Rue de la Loi 41 B-1049 Brussels.

Fabe A, Grote U, Winter E (2009). Value Chains Analysis Methodologies in the Context of Environmental and Trade Research. ResearchGate. Available https://www.researchgate.net/publication/45455633.

Fabe A, Grote U, Winter E (2011). Recent developments in applying environmental value chain analysis. Environmental Economics, 2 (3).

Bellù LG (2013). Value Chain Analysis for Policy Making: Methodological Guidelines and country cases for a Quantitative Approach. FAO-EASYPol, series 129.

Farahani RZ, Asgari N, Davarzani H (2009). Supply chain and logistics in national, international and governmental environment, concepts and models. London New York. Physica-Verlag Heidelberg. Pp. XVIII,316.

Gereffi G (1994). The Organization of Buyer-Driven Global Commodity Chains: How U.S. Retailers Shape Overseas Production Networks. Westport, Connecticut. Praeger.

Gereffi G, Korzeniewicz M, (eds.) (1994). Commodity Chains and Global Capitalism. Westport, Connecticut. Praeger. Gereffi G (1999). International trade and industrial upgrading in the apparel commodity chain. Journal of International Economics, 48. Pp. 37-70.

Gereffi G, Humphrey J, Sturgeon T (2005). The governance of the global value chains. Review of International Political Economy, 12 (1):17-104. DOI: 10.1080/09692290500049805.

Gereffi G, Fernandez-Stark K (2016). Global Value Chain Analysis: A
Primer - Second edition. Duke - Center on Globalization, Governance \& Competitiveness, Social Science Research Institute.

Gibbon P, Ponte S (2005). Trading Down: Africa, Value Chain, and the Global Economy. Philadelphia, Pennsylvania. Temple University Press.

Gibbon P, Bair J, Ponte S (2008). Governing global value chains: an introduction. Economy and Society, 37 (3):315-338. DOI: 10. 1080/03085140802172656.

GTZ (2007). ValueLinks Manual - the methodology of value chain promotion.

Hopkins TK, Wallerstein IM (1986). Commodity Chains in the World Economy Prior to 1800. Review, 10 (1):157-170.

Kaplinsky R (2000). Globalization and Unequalization: What can be learned from value chain analysis? The Journal of Development Studies, 37 (2):117-146. DOI: 10.1080/713600071.

Kaplinsky R, Morris M (2001). A Handbook for Value Chain Research. Working Paper Prepared for the IDRC. Institute for Development Studies, Brighton, UK.

Messner D (2002). The concept of the "World Economic Triangle": global governance patterns and options for regions. IDS, Working paper 173.

OECD (2016). Development AID at a Glance, Statistics by Region. 2. Africa. 2016 edition.

Oliver RK, Webber MD (1982). Supply-chain management: Logistics catches up with strategy, In Cristopher, M. 1992. Logistics: The strategic issues. Chapman \& Hall, London, pp. 63-75.

Parlamento Europeu (2015). Relatório sobre financiamento do desenvolvimento (2015\2044(INI)). Comissão do Desenvolvimento. Pedro S. Pereira, relator.

Simatupang T, Piboonrungroj P, Williams S (2017). The emergence of value chain thinking. International Journal of Value Chain Management, 8 (1) DOI: 10.1504/IJVCM.2017.10003558.

Pietrobelli C, Starritz C (2013). Challenges for Global Value Chain Interventions in Latin America. Inter-American Development Bank. Technical note, $\mathrm{n}^{\circ}$ IBD-TN-548.

Porter ME (1985). The Competitive Advantage: creating and sustaining superior performance. The free press: A division of Simon \& Schuster INC.

Raikes P, Jensen MF, Ponte S (2000). Global commodity chain analysis and the French filiére approach: comparison and critique. Economy and Society, 29 (3):390-417. DOI: 10.1080/03085140050084589.

Rich KM, Ross RB, Baker AD, Negassa A (2011). Quantifying value chain analysis in the context of livestock systems in developing countries. Food Policy, 36 (2):214-222. DOI: 10.1016/j.foodpol.2010.11.018.

Schmitz H (2005). Value Chains Analysis for Policy-Makers and Practitioners. International Labour Office, Geneva.

Sturgeon TJ (2009). From Commodity Chains to Value Chains: Interdisciplinary Theory Building in an Age of Globalization, in Jennifer Bair (ed). Frontiers of Commodity Chain Research. Stanford University Press, Stanford, California.

Svensson G (2007). Supply chain management versus sustainable chain management. EsicMarket, 129. Pp. 219-237.

Sweeney E (2010). Supply Chain change management: an internal and b2b relationship perspective. Supply chain perspectives. The Journals of the National Institute for Transport and Logistic, 11 (1):1821.

Trienekens $\mathrm{JH}$ (2011). Agricultural value chains in developing countries: A framework for analysis. International Food and Agribusiness Management Review, 14.Pp. 51-82.

Visser P, Steen M, Greiling J, Hayesso T, Neefjes R, Greijn H (eds.) (2012). Pro-Poor Value Chain Development; Private Sector-Led Innovative Practices in Ethiopia. SNV, Business Organizations and their Access to Markets - BOAM Programme.

Webber CM, Labaste P (2009). Building competitiveness in Africa's agriculture: a guide to value chain concepts and applications. The World Bank, Washington, DC. 187 pp. Available at: http://www.worldbank.org/pdt.

Zamora EA (2016). Value chain analysis: a brief review. Asian Journal of Innovation and Policy, 5 (002):116-128. DOI: http//dx.doi.org/10.7545/ajip.2016.5.2.116. 